\title{
BIOENERGETICS IN TWO PULMONATE SNAILS, HELISOMA AND PHYSA
}

\author{
Eugene H. Studier, Kim E. Edwards and Michael. D. Thompson \\ Department of Biology, University of Michigan-Flint, Flint, MI 48503, U.S.A.
}

(Received 23 May 1974)

\begin{abstract}
Energy budgets constructed for the pulmonate snails, Physa gyrina and Helisoma trivolvis, indicate:

1. Assimilation efficiency in wild type Physa (88.9 per cent) and Helisoma (73.2 per cent) are exceptionally high when compared to reported values for invertebrates while assimilation efficiency in an albino strain of Helisoma, although above average for most invertebrates, is comparatively low (59-8 per cent).

2. With a single exception, there are no relationships between weight or weight gain and food (energy) ingested, wastes (energy) egested, assimilation efficiency or energy devoted to reproduction.

3. Daily food energy ingested by wild $P$. gyrina $(27.5 \mathrm{cal} /$ day) and $\boldsymbol{H}$. trivolvis $(27.6 \mathrm{cal} / \mathrm{day})$ are similar and significantly higher than daily food energy ingested by albino $H$. trivolvis.(15.9 cal/day).

4. Albino $H$. trivolvis devoted more energy to egg production ( $2 \cdot 1 \mathrm{cal} /$ day) than did the wild variety (1.1 cal/day).

5. Secondary productivity of both varieties of $H$. trivolvis were exceptionally high $(17.8$ and 32.6 per cent).
\end{abstract}

\section{INTRODUCTION}

UNTIL recent years, investigations of energy budgets among metazoan invertebrates have been rare. Most of these studies of energy flow have utilized insects (Wiegert, 1964, 1965; Schroeder, 1973; van Hook \& Dodson, 1974), although some have dealt with molluses (Hughes, 1970; Burky, 1971). The fact that snails may be maintained indefinitely as well as grow and reproduce on a single defined diet in an isolated system (Mooij-Vogelaar \& Steen, 1973; Steen et al., 1973) suggests that some snails may provide excellent subjects for analysis of energy requirements and partitioning (Davis, 1962).

Energy budgets are characteristically based on the premise that ingested energy is grossly partitioned by organisms into energy egested and energy assimilated. The quotient of energy assimilated divided by energy ingested is taken to be the apparent digestibility coefficient (Brody, 1945; McDonald et al., 1966) or assimilation efficiency. Assimilated energy may be sub-divided into energy used in individual maintenance (metabolism), in individual growth and in population growth (reproduction). The present study yields data on gross energy use as well as energy partitioning in a laboratory strain and a wild population of Helisoma trivolvis and a natural population of Physa gyrina.

\section{MATERIALS AND METHODS}

Snails of both species were collected from natural populations in early November 1973 from a small stream running adjacent to the campus. These snails, hereafter referred to as "wild" varieties, were maintained in aerated stream water and acclimated to room temperature $\left(22^{\circ} \mathrm{C}\right)$ for 2 days prior to experimentation. The Physa used in this study were identified using the male genital characteristics as described by Clampitt (1970). In addition to these wild Helisoma trivolvis and Physa gyrina, individuals from an albino laboratory-raised strain of $\boldsymbol{H}$. trivolvis maintained by Dr. G. L. Pace of this department were studied. These individuals were kept in commercially purchased spring water. In all cases, larger individuals were chosen for study to maximize data values.

The initial wet weight was determined $(0.001 \mathrm{~g})$ and each snail was placed in a full 6-oz. clear plastic container. About twenty individuals of each variety were used. An excess of pre-weighed head lettuce served as food. Snails were maintained in this aerated water for a period of 8 days. Evaporative water loss was replaced daily. The daily light cycle was approximately $12 \mathrm{hr}$ light: $12 \mathrm{hr}$ dark, centered at 0800 hours local time.

At the termination of the feeding trials, final weights of snails, lettuce, feces and eggs were determined and differences calculated. Lettuce, feces and egg samples were dried to constant weight at $60-65^{\circ} \mathrm{C}$ and caloric contents determined with a Parr oxygen bomb calorimeter.

\section{RESULTS}

Caloric content of both wild and albino $H$. trivolvis feces was $4 \cdot 109 \mathrm{kcal} / \mathrm{g}$ dry weight, while that of $P$. gyrina feces was $3.506 \mathrm{kcal} / \mathrm{g}$ dry weight. Egg masses produced by $H$. trivolvis contained $4.273 \mathrm{kcal} / \mathrm{g}$ dry weight. No eggs were produced by 
Table 1. Daily energy ingested $(I)$, egested $(W)$ and assimilated $(A)$ by $H$. trivolvis and $P$. gyrina. Assimilated energy is partitioned into energy used in growth $(G)$, and reproduction ( $E=$ egg energy) with the remaining energy used in maintenance or metabolism $(M)$

\begin{tabular}{|c|c|c|c|c|c|c|c|c|c|c|}
\hline Species & $N$ & A.E. & $W t$ & $\Delta \mathrm{Wt}$ & $I$ & $W$ & $A$ & $E$ & $G$ & $M$ \\
\hline $\begin{array}{l}P . \text { gyrina } \\
\text { H. trivolvis (wild) } \\
\text { H. trivolvis (albino) }\end{array}$ & $\begin{array}{l}17 \\
19 \\
20\end{array}$ & $\begin{array}{l}88 \cdot 9 \\
73 \cdot 2 \\
59 \cdot 8\end{array}$ & $\begin{array}{l}0 \cdot 156 \\
0 \cdot 468 \\
0 \cdot 398\end{array}$ & $\begin{array}{l}-0.47 \\
+2 \cdot 81 \\
+2 \cdot 28\end{array}$ & $\begin{array}{l}27 \cdot 53 \\
27 \cdot 61 \\
15 \cdot 94\end{array}$ & $\begin{array}{l}3 \cdot 07 \\
7 \cdot 73 \\
6 \cdot 40\end{array}$ & $\begin{array}{r}24 \cdot 46 \\
20 \cdot 20 \\
9 \cdot 54\end{array}$ & $\begin{array}{l}0 \\
1 \cdot 12 \\
2 \cdot 11\end{array}$ & $\begin{array}{r}-0.63 \\
3.79 \\
3.09\end{array}$ & $\begin{array}{r}25 \cdot 09 \\
15 \cdot 29 \\
4 \cdot 34\end{array}$ \\
\hline
\end{tabular}

Assimilation efficiency (A.E.) is expressed as a percentage $(100 \times A / I)$; mean individual weight (Wt) is in $\mathrm{g}$; growth $(\Delta \mathrm{Wt})$ is in $\mathrm{mg} /$ day; and all other values are in cal/day.

$P$. gyrina during the experimental time period. Caloric content of several lettuce samples which had been water-soaked for varying periods of time remained constant at $152.4 \mathrm{cal} / \mathrm{g}$ wet weight. Daily energy consumption and partitioning among the tested snails are shown in Table 1.

Values for $M$ (maintenance or metabolism) in Table 1 are the only numbers derived by difference, having not been specifically determined experimentally. Converting this caloric data for $M$ into oxygen consumption values, we find approximate values of $1.39 \mathrm{~cm}^{3} \mathrm{O}_{2} / \mathrm{g}$ per hr for $P$. gyrina; 0.273 $\mathrm{cm}^{3} \mathrm{O}_{2} / \mathrm{g}$ per $\mathrm{hr}$ for wild $H$. trivolvis; and $0.094 \mathrm{~cm}^{3}$ $\mathrm{O}_{2} / \mathrm{g}$ per hr for albino $H$. trivolvis. These values fall reasonably close to expected oxygen consumption values as predicted from data for other snails (Fitch, 1975). Energy devoted to growth is estimated by assuming 80 per cent of wet weight change to be water (Fitch, 1975) and assuming a caloric content of $5.0 \mathrm{kcal} / \mathrm{g}$ dry weight (Hughes, 1970; Studier, unpublished data).

Analyses of variance and regression analyses were performed on initial weight, final weight and rate of weight change (growth) as affected by or related to food or energy ingested, waste or waste energy egested, number of eggs deposited, egg weight or egg energy and assimilation efficiency. In only one case was a significant relationship found: for wild $H$. trivolvis, food or energy ingested was directly related to initial weight $(F=7.20 ; 1$ and 18 d.f.; $P=0.0152)$ and final weight $(F=7.80 ; 1$ and 18 d.f.; $P=0.0120$ ). No other significant relationships were found.

\section{DISCUSSION}

Hughes (1970) summarized most of the previously published data concerning energy budgets and partitioning among invertebrates, including values for assimilation efficiencies $(100 \times A / I)$; net growth efficiencies $[100 \times(E+G) / A]$ and ecological efficiency or secondary productivity $[100 \times(E+G) / I]$. Values for the assimilation efficiencies (A.E.) of the snails presently under consideration have been given in Table 1. The A.E. for wild-type Physa and Helisoma are considerably higher than those reviewed by Hughes (1970) or reported for other invertebrates (Wiegert, 1965; Schroeder, 1973; van Hook \&
Dodson, 1974), and in fact fall into normal ranges for ectothermic vertebrates (e.g. see Throckmorton, 1973; Kepenis \& McManus, 1974) and even small mammals (see O'Farrell et al., 1971). The extraordinarily high assimilation efficiencies of the wild varieties tested may be reflective of excessive activity or relatively higher weight specific oxygen consumption of these small species, particularly evident in Physa. The low A.E. of the albino variety of Helisoma falls among the higher literature reports for invertebrates and would seem to indicate a system which is relatively efficient when compared to other invertebrates. These albino Helisoma comprise a small percentage of natural populations of this species (Pace, personal communication). The significantly lowered A.E. in albino Helisoma may account for the inability of this variety to compete with wild Helisoma under natural conditions.

Net growth efficiency and ecological efficiency or secondary productivity approximated zero for $P$ hysa during this experimentation even though excess food was provided. Previous studies by van der Schalie \& Berry (1973) indicated that significant growth in both Physa and Helisoma could be expected over an 8-day period at $22^{\circ} \mathrm{C}$. Net growth efficiency of wild and albino Helisoma were 24.3 and 54.5 per cent, respectively; while ecological efficiency for the wild and albino varieties were 17.8 and 32.6 per cent, respectively. These indices of relative energy fixation or secondary productivity are among the highest values thus far reported, particularly the 32.6 per cent for albino Helisoma. Both wild and albino Helisoma partitioned large amounts of energy into egg production, $4 \cdot 1$ and 13.2 per cent of total daily energy ingested, respectively, which accounts for a major portion of secondary productivity in this species.

It is surprising that there are so few relationships between body weight or growth and food (energy) ingested, waste (energy) egested or assimilation efficiency. As indicated for other snails (Fitch, 1975), a partial explanation for this phenomenon may involve excessive activity and, therefore, excessive food requirements for smaller individuals coupled to lowered activity and maintenance energy in larger individuals. The lack of a relationship of weight or growth rate to either ingested or egested energy 
apparently precludes any relationship of these parameters to assimilation efficiency. In view of the relatively large amounts of energy relegated to egg production in Helisoma, the lack of a relationship between size (weight) and energy devoted to reproduction is also surprising.

Acknowledgements-We thank Dr. Gary L. Pace for providing the albino Helisoma and for his identification of the snails. Drs. Pace and R. W. Dapson reviewed this manuscript.

\section{REFERENCES}

Brody S. (1945) Bioenergetics and Growth. Reinhold, New York.

BURKY A. J. (1971) Biomass turnover, respiration, and interpopulation variation in the stream limpet Ferrissia rivularis (Say). Ecol. Monogr. 41, 235-251.

ClampItT P. T. (1970) Comparative ecology of the snails Physa gyrina and Physa integra (Basommatophora: Physidae). Malacologia 10, 113-151.

Davis G. M. (1962) A theoretical model for measuring secondary productivity in mollusks. Ann. Rep. Am. Malacol. Union p. 4.

Frrce D. D. (1975) Oxygen consumption in the prosobranch snail Viviparus contectoides (Mollusca: Gastropoda)-I. Effects of weight and activity. Comp. Biochem. Physiol. 51A, 815-820.

Hughes R. N. (1975) An energy budget for a tidal-flat population of the bivalve Scrobicularia plana (da Costa). J. Anim. Ecol. 39, 357-381.

KePENIS V. \& MCMANUS J. J. (1974) Bioenergetics of young painted turtles, Chrysemys picta. Comp. Biochem. Physiol. 48A, 309-317.

McDonald P., Edwards R. A. \& Greenhalgh J. F. D. (1966) Animal Nutrition. Oliver \& Boyd, London.
Mooij-VogelaAr J. W. \& VAN DeR StTen W. J. (1973) Effects of density on feeding and growth in the pond snail Lymnaea stagnalis (L.) Proc. K. Ned. Acad. Wet., Ser. C 76, 61-68.

O'Farrell. M. J., Studier E. H. \& Ewing W. G. (1971) Energy utilization and water requirements of captive Myotis thysanodes and Myotis lucifugus (Chrioptera). Comp. Biochem. Physiol. 39A, 549-552.

SCHROEDER L. A. (1973) Energy budget of the larva of the moth Pachysphinx modesta. Oikos 24, 278-281.

Throckmorton G. (1973) Digestive efficiency in the herbivorous lizard Ctenosaura pectinata. Copeia 1973, 431-435.

VAN DER SchaliE H. \& BerRy E. G. (1973) The effects of temperature on growth and reproduction of aquatic snails. Sterkianta 50, 1-92.

VAN DER STEen W. J., JAGer J. C. \& Tiemersma D. (1973) The influence of food quality on feeding, reproduction and growth in the pond snail Lymnaea stagnalis $(\mathcal{L}$.) with some methodological comments. Proc. $K$. Ned. Acad. Wet., Ser. C 76, 47-60.

VAN Hook R. I,, JR. \& Dodson G. J. (1974) Food energy budget for the yellow-poplar weevil, Odontopus calceatus (Say). Ecol. 55, 205-207.

Wiegert R. G. (1964) Population energetics of meadow spittlebugs (Philaenus spumarius L.) as affected by migration and habitat, Ecol. Monogr. 34, 217-241.

WiEgerT R. G. (1965) Energy dynamics of the grasshopper populations in old field and alfalfa field ecosystems. Oikos 16, 161-176.

Key Word Index-Bioenergetics; growth energy; maintenance energy; reproduction energy; snails; pulmonate; assimilation efficiency; secondary productivity; ecological efficiency. 